\title{
Essential irrigation and the economics of strawberries in a temperate climate
}

\author{
Morris, $\mathrm{J}^{1}$, Else, M.A ${ }^{2}$, El Chami, D. ${ }^{3}$, Daccache, A. ${ }^{4}$, Rey, $\mathrm{D}^{1}$ and Knox, J.W ${ }^{1, *}$ \\ ${ }^{1}$ Cranfield University, Cranfield, Bedfordshire MK43 OAL, UK \\ ${ }^{2}$ NIAB EMR, Kent, ME19 6BJ, UK \\ ${ }^{3}$ Timac Agro Italia, S.P.13 - Località Ca' Nova, I-26010 - Ripalta Arpina (CR), Italy \\ ${ }^{4}$ University of California, Davis, One Shield Avenue, Davis, CA 95616-5270, USA \\ * Corresponding author: j.knox@ @ cranfield.ac.uk
}

\begin{abstract}
Strawberries are a high value crop in the UK soft fruit sector, with the majority of production grown at field-scale and under protected (polytunnel) conditions. Despite its importance to the rural economy, there is surprisingly little published scientific evidence on the economics of irrigated strawberry production and the value of water in this horticultural sector. A survey of growers, supplemented by secondary data and industry sources, shows considerable variation in key physical and financial performance indicators, both within and between different strawberry production systems, as well as evidence of good practice. Water application depths ranged widely from 800 to over $2,000 \mathrm{~m}^{3} \mathrm{ha}^{-1}$ according to grower and crop variety. Irrigation costs typically range between $£ 1.30$ and $£ 2.50 \mathrm{~m}^{-3}$ of water applied, highest where storage reservoirs and public water supplies are used. The average value of irrigation water for strawberry net of costs was about $£ 6 \mathrm{~m}^{-3}$, much higher than for field crops such as potatoes. The importance of a reliable water supply to support irrigated strawberry production is highlighted. Climate change and growing pressures on water resources are likely to force a greater interest in irrigation economics in the soft fruit sector, especially in the face of restrictions on summer abstraction and rising competition and charges for using public water supply.
\end{abstract}

Keywords: costs and benefits; water use efficiency; horticulture; soft fruit; water value.

\section{Introduction}

The UK soft fruit sector has experienced a strong and sustained period of growth over the last two decades, with the fruit increasing in popularity each year due to its nutritional and dietary characteristics and to advances in post-harvest storage and processing (Nour et al., 2011). In addition to fresh consumption, the fruit can also be frozen, processed and dried, thus having a wide range of uses in both the fresh (supermarket) and processed sectors. Despite its increased economic importance to some regional rural economies, there is surprisingly little published scientific evidence on the economics of strawberry production. In the UK, strawberry plantings have increased by over $30 \%$ since 2000 , exceeding 4,500 hectares in 2015 and producing about 115,000 tonnes of marketable fruit (Figure 1) valued at $c £ 284$ million, equivalent to approximately $39 \%$ of the total value of national fruit sector production (Defra, 2015). The domestic sector has further growth potential as a third (32\%) of the total UK market supply in 2015 was imported (Defra, 2015). Growers in the UK now regard irrigation as an essential component of production to increase yield and quality and to increase levels of local production to substitute for imported products (Defra, 2010; Knox et al., 2009; Knox and Hess, 2014). The English Food and Farming Partnerships (EFFP), however, report that short term seasonal changes in UK weather could generate large fluctuations in future demand-supply balances which would make it even more difficult for UK growers to meet consumer demand (EFFP, 2010). 
Else and Atkinson (2010) reported on the impacts of climate change on irrigation water demand for strawberries in the UK that would most likely lead to a substantial increase in water abstraction and irrigation costs. For soft fruit, including strawberries, they reported that the main concern related to increasing temperatures and the consequent increase in evaporative demand, plant transpiration rates, and hence crop water use. An extended growing season due to warmer temperatures would exacerbate the situation. Climate change would also result in reduced summer rainfall, particularly in south east England where most strawberries are grown (Figure 2), where sectoral competition for water is most acute and where available water resources are most constrained (Hess et al., 2010). In addition, a number of water regulatory and policy reforms are underway, including changes in the water abstraction licensing regime for agricultural and horticultural irrigation (Defra, 2014a); these are likely to reduce the reliability of summer water availability, increase water supply risks, and significantly increase the cost and marginal value of water abstracted for irrigation. As a consequence, the composition of irrigated production is changing radically with the introduction of abstraction licences for previously unregulated trickle (or drip) irrigation users (mainly targeting the soft fruit sector), widespread investments in winter (high flow) storage reservoirs to provide guaranteed water supplies for summer irrigation, rising costs of public water supplies currently used by some growers and increasing retailer demands for product traceability and quality assurance (Knox et al., 2012). Collectively, these factors are having a profound impact on the economics of strawberry irrigation in the UK and on the economics of strawberry production as a whole.

In terms of geographical distribution, strawberry is the iconic soft fruit crop grown in many areas of the UK including the southeast, east and west Midlands regions of England (Figure 2) and southeast Scotland, representing half of the total UK soft fruit area (Rey et al., 2016). All of these areas in England are classified by the water regulatory authority, the Environment Agency (EA), as being either "over-abstracted" and/or "over-licensed" (Knox et al., 2009), despite the fact that the UK is characterised by a temperate climate with generally sufficient summer rainfall. Although strawberry production is geographically widely dispersed across the UK, most is concentrated in east and south eastern England. The climate characteristics in this region in terms of rainfall, temperature and reference evapotranspiration (ETo) can be broadly defined as follows. Based on long-term historical daily climate data for 1961-90, the mean rainfall in the region is $\mathrm{c} 50 \mathrm{~mm}$ month $^{-1}$, mean daily summer temperatures are $\mathrm{c} 16{ }^{\circ} \mathrm{C}$ (ranging from 11 to $21^{\circ} \mathrm{C}$ in July) and peak ETo rates are typically 3.0 to $4.5 \mathrm{~mm} \mathrm{~d}^{-1}$. Irrigation is therefore supplemental to rainfall. The majority of UK strawberry production is now grown in substrate (soil-less) and under protected conditions (temporal or permanent polytunnel structures, or glasshouses) due to concerns regarding effective soil sterilisation and the drive to reduce harvest labour costs (NHF, 2011; Knox et al., 2013). Field-grown strawberries can generally be classified into three main groups. First, '60-day' strawberries are planted in spring and begin cropping approximately 60 days after planting. After cropping, flower initiation occurs in late summer and autumn and the plants are left to overwinter. The following year, these become what are usually termed 'main-season crop' (or raised bed) strawberries which are typically harvested from late May through to end July. The crop is then replanted the following season. Third, 'everbearer' strawberries are usually planted in spring and cropped for only one year, beginning in early June continuing through to October. Some growers now retain everbearer crops for two and occasionally three years. In this paper, we therefore refer to two distinct categories, '60-day/main-season' and 'everbearer'.

Data on the economics of strawberry production mainly comprise broad assessments based on industry sources published in farm management handbooks (Nix, 2011; ABC, 2012) and 
national scale statistics on the production of soft fruit (Defra, 2014b; 2015). There are no known scientific studies assessing the economics of irrigated strawberry production. The aim of this study was thus to provide new insights into irrigation water management practices and the value of irrigation water in this sector, both with a view to support farmer decisionmaking regarding irrigation management practices and to inform water resource managers regarding the importance and value of water used in the sector in the face of increasing resource pressures in water stressed catchments. The specific objectives were to identify, develop and apply indicators to assess irrigation performance at the farm-scale for the main types of strawberry production, to assess the benefits and costs of irrigation to farmers, and hence the value of irrigation water in the sector. The methods and materials are briefly described below, followed by the results and implications for agricultural water management practice and policy.

\section{Material and methods}

The enquiry built on an initial postal and telephone survey of irrigation practices of 21 strawberry growers in England initially carried out in 2010 growing season. This was subsequently followed up in the 2011 season with a personal interview of a subset of 13 growers willing to provide detailed information on irrigation water use, alongside other data to enable a comparative assessment of practices (Else, 2012). This sample covered 434 ha in the southern and central parts of England, accounting for about 10\% of the total UK strawberry cropped area. Three main types of production system were included, namely: 60day (11 growers, $23 \%$ of the total sample area); main-season (12 growers, $48 \%$ ) and everbearer (9 growers, 29\%). It is important to emphasise that the 60-day crop is the first year of the main-season crop variety.

Estimates were derived of selected performance indicators by individual grower, by production system and for the sample as a whole as follows:

- Irrigation water volume applied

$$
\begin{aligned}
& \left(\mathrm{m}^{3} \mathrm{ha}^{-1}\right) \\
& \left(\text { tonnes Class } 1 \mathrm{ha}^{-1}\right) \\
& \left(\mathrm{kg} \text { Class } 1 \mathrm{~m}^{-3}\right) \\
& (£ \text { tonne } \\
& (£ \text { Class } 1) \\
& \left(£ \mathrm{ha}^{-1}\right) \\
& \left(£ \mathrm{~m}^{-3}\right)
\end{aligned}
$$

- Irrigation water use efficiency

- Product value

- Output per irrigated area

- Output per unit of water applied

Data were grouped and analysed for each cropping system to produce mean, minimum and maximum values, and the inter quartile ranges. Irrigation volumes were based on actual recorded volumes applied $\left(\mathrm{m}^{3} \mathrm{ha}^{-1}\right)$ where available or otherwise estimated from known system application rates $\left(\mathrm{m} 3 \mathrm{~h}^{-1}\right)$ and reported durations $\left(\mathrm{h} \mathrm{ha}^{-1)}\right.$. The yield of Class 1 fruit, which typically equates to $>90 \%$ of harvested fruit was the main physical output indicator. Class 1 is defined as berries greater than $25 \mathrm{~mm}$ in diameter, with a minimum soluble solids content (SSC[\%BRIX]) of 8 as required by major retailers. Berries must also be clean and free from blemishes.

The relatively small sample sizes in each group limit the extent to which parametric statistical analyses can be applied but where possible significant differences in mean indicator values between groups are identified.

In order to explore the benefits, costs and 'added value' of irrigation for strawberries, a further follow-up questionnaire was sent to seven (of the aforementioned 13) selected growers. Four growers completed the questionnaire that was then followed up by face-to-face (3) and telephone (1) discussions. Representatives of two producer organisations, an agricultural advisor and irrigation design and installation specialist were also contacted. These survey data 
were supplemented by strawberry enterprise data from published farm business management sources (Nix, 2011: ABC, 2012). All prices are for the production year 2011/12.

The value of water in strawberry production was estimated as follows:

$$
\mathrm{V}=(\mathrm{Y} . \mathrm{P}-\mathrm{C}) / \mathrm{W}
$$

Where;

$\mathrm{V}$ : gross margin based value of water $\left(£ \mathrm{~m}^{-3}\right)$

Y: average saleable yield of strawberries $\left(\mathrm{t} \mathrm{ha}^{-1}\right)$

P: average sale price obtained $\left(£ \mathrm{t}^{-1}\right)$

$\mathrm{C}$ : variable costs of strawberry production $\left(£ \mathrm{ha}^{-1}\right)$

$\mathrm{W}$ : average depth of irrigation water applied $\left(\mathrm{m}^{3} \mathrm{ha}^{-1}\right)$

The value of irrigation water $\left(£ \mathrm{~m}^{-3)}\right.$ was expressed both in terms of gross output ((Y.P)/W above) and gross margin ((Y.P $-\mathrm{C}) / \mathrm{W}$ above). While information on strawberry Class 1 yield and prices and hence gross output per ha were available from all sampled growers, detailed data on variable costs were not. A review of published data together with information from four growers and from industry sources enabled estimates of variable costs and hence gross margins to be made.

The added value of water in supplementary irrigation can be also assessed by comparing gross margins between an irrigated crop and an equivalent rainfed crop. However, the growers involved in this study reported that rainfed strawberry production was commercially unviable (yields would be too low and of highly variable quality). Thus, without access to irrigation they would revert to the most common rainfed crop in England which is winter wheat (termed the 'counterfactual'). For this reason, the average added value of water in strawberry production was measured relative to the counterfactual of rainfed wheat, given by:

$$
\mathrm{V}^{*}=(\mathrm{V} \cdot \mathrm{W}-\mathrm{G}) / \mathrm{W}
$$

Where;

$\mathrm{V}^{*}$ is the gross margin value added $\left(£ \mathrm{~m}^{-3}\right)$ from strawberry production relative to rainfed wheat production, and $\mathrm{G}$ is the adjusted gross margin of wheat $\left(£ \mathrm{ha}^{-1}\right)$ after deducting variable production and marketing costs obtained from published sources. Here $\mathrm{V}=£ 530 \mathrm{ha}^{-1}$ is assumed, based on $£ 700 \mathrm{ha}^{-1}$ gross margin minus $£ 170 \mathrm{ha}^{-1}$ other direct costs (Nix 2011; ABC, 2012). Although, the value added by water in supplementary irrigation can be assessed by comparing gross margins between irrigated and rainfed crop, most growers argued that rainfed strawberry production was commercially infeasible without irrigation.

\section{Results}

For the sample of growers involved, this section summarises the key findings relating to an analysis of three key physical performance indicators covering water use, crop productivity and irrigation water use efficiency, and three key financial performance indicators, including product value, the output per unit of irrigated area and output per unit of irrigation water.

\subsection{Physical performance indicators}

Figure 3 shows the results derived from a sample of 21 growers for three indicators of physical performance, namely water use, crop productivity and irrigation water use efficiency for three types of strawberry crop. Mean water use (unweighted by area) was about $800 \mathrm{~m}^{3} \mathrm{ha}^{-}$ ${ }^{1}, 1,000 \mathrm{~m}^{3} \mathrm{ha}^{-1}$ and $1,450 \mathrm{~m}^{3} \mathrm{ha}^{-1}$ on 60 -day, main-season and everbearer strawberries, 
respectively (Figure 2a), with considerable variation about these means. Weighted by sample areas and water usage, these estimates are $830 \mathrm{~m}^{3} \mathrm{ha}^{-1}, 990 \mathrm{~m}^{3} \mathrm{ha}^{-1}$ and 1,760 $\mathrm{m}^{3} \mathrm{ha}^{-1}$ respectively. For 60-day varieties, applications are skewed towards lower volumes with 75\% of growers applying less than $1000 \mathrm{~m}^{3} \mathrm{ha}^{-1}$. Average and median volumes are higher for mainseason and everbearer but with greater sample variation. Growers at or below the $25 \%$ quartile for each production system may be regarded as indicative of 'best practice' (growers 6 and 8 for 60 -day varieties, and growers 8,13 for everbearer) although it is appropriate to consider crop productivity simultaneously. Some growers were consistent in the water management practices across all production types (e.g. grower 8) whereas others showed greater variation between strawberry production systems (e.g. grower 17).

Overall, the median yields for main-season and everbearer crops were similar at approximately $23 \mathrm{t} \mathrm{ha}^{-1}$ and higher than the median for 60-day varieties estimated to be $18 \mathrm{t}$ ha $^{-1}$ (Figure 2b). Class 1 yields from 60-day crops in 2011 varied widely, indicated by the relatively large interquartile and overall ranges. Yields from 60-day crops were skewed to the left and $75 \%$ of growers achieved yields of less than $21 \mathrm{tha}^{-1}$; the median value was $18 \mathrm{tha}^{-1}$. The median yield from main-season and everbearer crops was greater than the third quartile of yields harvested from 60-day crops. Grower 3, for example, returned consistently high yields across all three strawberry types. Grower 7, with high yields on 60-day crops, reported late frost and mildew damage on the main crop, indicating likely seasonal variations in performance. For this small sample of 32 cases across three crop systems, analysis showed that water use can explain only about $11 \%$ of observed variation in Class 1 strawberry yields $\left(\mathrm{R}^{2}=0.11, \mathrm{p}=0.06\right)$. Thus, other (non-normally distributed) factors, including strawberry varieties, management and irrigation practices, and local factors such as soil and weather are likely to account for approaching $90 \%$ observed variation. There appears to be a stronger relationship for the small sample (9) of everbearer growers considered separately where irrigation water use explains about $39 \%$ of observed variation in yields $(\mathrm{p}=0.07)$.

Overall mean irrigation water use efficiency (IWUE) (Figure 2c) was $30.2 \mathrm{~kg}$ Class $1 \mathrm{~m}^{-3}$, ranging widely from 8.8 to $61.5 \mathrm{~kg} \mathrm{~m}^{-3}$, evident for example in the large interquartile range for the 60-day crop. Half of 60-day variety growers achieved less than $27 \mathrm{~kg} \mathrm{~m}^{-3}$ while the average was $34 \mathrm{~kg} \mathrm{~m}^{-3}$. There was no significant difference in IWUE between 60 day and main varieties (average $32 \mathrm{~kg} \mathrm{~m}^{-3}$ ), but IWUE for everbearers was significantly lower at $22 \mathrm{~kg}$ $\mathrm{m}-3$ ( $\mathrm{p}=0.10)$ mainly reflecting higher water volumes applied over a longer growing season. There is an eight to ten fold difference between the maximum and minimum IWUE values within crop types, again with wide variation between growers. Consistently high results were achieved by Grower 8, compared with Grower 20 who achieved relatively low IWUE across all types. Performance can also be measured in terms of water productivity $\left(\mathrm{m}^{3}\right.$ Class $1 \mathrm{t}^{-1)}$, the inverse of IWUE. Overall, an average of $51.3 \mathrm{~m}^{3}$ Class $1 \mathrm{t}^{-1}$, ranging from 16.7 to 113.2 $\mathrm{m}^{3}$ Class $1 \mathrm{t}^{-1}$.

\subsection{Financial performance}

Figure 3 shows selected indicators of financial performance for 21 growers, namely product value, output per unit of irrigated area and output per unit of irrigation water. Product value (Figure 3a) expressed in prices received for saleable produce averaged $£ 3.100 \mathrm{t}^{-1}$, ranging between $£ 2,800$ and $£ 3,400 \mathrm{t}^{-1}$ with relatively low interquartile distribution, mainly reflecting the timing of market sales for a specified quality grade. Overall everbearers returned higher average prices than 60-day and main-season crops because this longer harvesting season enabled growers to avoid some periods of oversupply.

Median output per irrigated area $\left(£ \mathrm{ha}^{-1}\right)$ was about $£ 40 \mathrm{k} \mathrm{ha}^{-1}, £ 75 \mathrm{k} \mathrm{ha}^{-1}$, and $£ 75 \mathrm{k} \mathrm{ha}^{-1}$, for 60-day, main-season and everbearer crops respectively in 2011, reflecting higher yields in the 
latter two crops, and higher 'out of season' prices for everbearer (Figure 3b). Relatively high prices for timely marketing helped growers 7 and 9 achieve high values for 60 day and everbearer, respectively.

Output per unit of water applied $\left(£ \mathrm{~m}^{-3}\right)$ varied considerably amongst the three cropping types (Figure 3c), with mean values (unweighted by share of total sample water use) of just over $£ 100 \mathrm{~m}^{-3}$ for the 60 day and main-season crops, and just over $£ 50 \mathrm{~m}^{-3}$ for everbearer. The interquartile range was greatest for 60-day crops indicating a larger sample variance. The minimum and maximum values were $£ 23 \mathrm{~m}^{-3}$ and $£ 214 \mathrm{~m}^{-3}$, respectively. Half (50\%) of the sampled growers generated more than $£ 81 \mathrm{~m}^{-3}$ applied. In main-season crops, the interquartile range was smaller than the corresponding 60-day value but the median and mean values were similar. The mean and the interquartile range of $£ \mathrm{~m}^{-3}$ values were lower for everbearer crops compared with other cropping types, reflecting the prolonged need for irrigation during the extended everbearer season. There was however, no significant difference (at $p<0.1)$ in mean output value per unit of water applied $\left(£ \mathrm{~m}^{-3}\right.$ ) between the varieties (overall mean $£ 82.9 \mathrm{~m}^{-3}$ unweighted by water volumes), indicating that although water volumes were higher on everbearer variety, this was offset by higher relative yields and seasonal product prices. Growers 7, 8 and 21 showed consistently high output values per unit of water across all of their crop types.

As well as these three financial performance indicators, it is important to consider the profitability of irrigated strawberry production, net of costs, and hence the value-added of water applied $\left(£ \mathrm{~m}^{-3}\right)$. For reasons discussed below, it proved difficult to obtain complete information from our sample growers about costs and profitability. Estimates of production costs from published and industry sources indicate that labour costs now account for between $40 \%$ and $60 \%$ of gross revenue. About $50 \%$ of total costs are associated with the actual production of strawberries including irrigation, 35\% with grading, marketing and packing, and about $15 \%$ for general overhead expenses.

Irrigation costs are usually included in strawberry production costs in published data, mainly under structures and 'other' costs. Table 1 shows estimates of irrigation costs derived for three selected cases from our sample. The total average costs ranged between $£ 1.30 \mathrm{~m}^{-3}$ and $£ 2.50 \mathrm{~m}^{-3}$, mainly varying according to scale, the need for winter storage reservoirs and the proportion of expensive public (domestic) mains water that is used. It is noted that while direct abstraction is the cheaper option if water is available, reservoir costs at around $£ 0.40 \mathrm{~m}^{-}$ ${ }^{3}$ to $£ 0.50 \mathrm{~m}^{-3}$ are lower than the cost of public water at $£ 0.80 \mathrm{~m}^{-3}$ to $£ 0.90 \mathrm{~m}^{-3}$.

Assuming an average of $£ 1.75 \mathrm{~m}^{-3}$ and observed average application volumes (weighted by area) from our sample of growers of $910 \mathrm{~m}^{3} \mathrm{ha}^{-1}$ for 60-day/main-season crop combination and $1,760 \mathrm{~m}^{3} \mathrm{ha}^{-1}$ for and everbearer crops respectively gives average irrigation costs of around $£ 1,600 \mathrm{ha}^{-1}$ and $£ 3,000 \mathrm{ha}^{-1}$, respectively, with a possible range of about $+/-50 \%$ given the considerable variation across all systems and practices. At these rates, irrigation costs probably account for between $4 \%$ and $8 \%$ of total average costs, highest where public or stored water is used.

Table 2 combines information from published and industry sources with our survey results to provide comparative estimates of annual revenues and variable costs and gross margins ( $£$ ha ${ }^{1}$ and $£ \mathrm{~m}^{-3}$ ) for 60 -day/main-season and everbearer crops. The survey based estimates for financial returns and water use in Table 2 are weighted by areas in the sample. Gross output per unit of water (weighted here by areas and hence the share of total water use) is $£ 70 \mathrm{~m}^{-3}$ for the 60 -day/main-season crop and $£ 49 \mathrm{~m}^{-3}$ for the everbearer crop, with wide ranges in possible value. Average gross margins for surveyed growers are $£ 6.60 \mathrm{~m}^{-3}$ and $£ 4.90 \mathrm{~m}^{-3}$ in 2011 prices for 60-day/main-season crop and everbearer varieties respectively, (equivalent to 
$£ 7.2 \mathrm{~m}^{-3}$ and $£ 5.4 \mathrm{~m}^{-3}$ in 2017 prices using GDP deflators, (ONS, 2017), with a wide range of observations. It is noted that gross margin is not a measure of profit as such because it does not include farm level fixed costs for buildings, regular labour, rent and rates and general overheads. The extent to which the published gross margins fully cover all costs associated with irrigation is not entirely clear, but it was assumed here that all direct costs associated with growing the crops, including irrigation equipment, infrastructure and operating costs are included.

Using wheat as a counterfactual, the estimated average added value of water (assuming area weighted water volumes) reduces slightly from the above estimates to $£ 6 \mathrm{~m}^{-3}$ for 60 day/mainseason crop varieties and $£ 4.6 \mathrm{~m}^{-3}$ for everbearer varieties (in 2011 prices), with values ranging between $£ 1 \mathrm{~m}^{-3}$ and $£ 13 \mathrm{~m}^{-3}$. It is noted that horticultural farms tend to have higher average fixed $\left(£ \mathrm{ha}^{-1}\right)$ than cereal farms (El Chami et al., 2015) and this would tend to reduce the estimates of the added value of water in strawberry production.

\section{Discussion}

\subsection{Irrigation water management practices and value of irrigation}

Our survey of strawberry producers showed considerable variation in key performance indicators with respect to the efficiency and value of water use in irrigation. The volumes of water applied per hectare of crop differed not only between growers but also between the three crop types produced by the same grower. Most growers who produced all three cropping types applied more water to main-season than 60-day plants and more water to everbearer than to main-season crops. The highest IWUE values achieved, by three growers $(7,8$ and 21 in Figure 2c) across all three cropping systems and were indicative of 'best practice'. Knox et al., (2013) reported that such best management practices were associated with adopting more objective scientifically based scheduling of irrigation applications using in-situ soil moisture measurement techniques (e.g. capacitance probes) and monitoring crop water demand, rather than reliance on subjective methods including experience and 'feeling the soil'.

Discussions with key informants from the soft fruit sector indicated that while the industry had expanded in response to market growth, profit margins had fallen in real terms mainly as a result of increased labour costs $\left(£ \mathrm{ha}^{-1}\right)$, partly associated with a doubling of yields and a move to protected cropping. In 2000, labour was estimated to account for about $20 \%$ to $25 \%$ of gross revenue whereas now it typically exceeds $50 \%$.

\subsection{Water management and policy implications}

Our results suggest that although irrigation currently accounts for about $5 \%$ of total strawberry production costs in most cases, this share is likely to increase. There is a gradient of costs in the supply of irrigation water. Currently the least cost source, where licences are available, is direct summer abstraction, with charges set at about $£ 0.06 \mathrm{~m}^{-3}$ depending on region to cover the administrative costs of the licensing system. However, in Anglian and Southern regions where most strawberry production and irrigation demand are concentrated (Figure 2) many catchments are now 'closed' for additional summer abstraction, with water only being available at high flows (typically winter). Abstracting winter water for use in the following summer therefore necessitates storage. The reservoir costs associated with winter abstraction increase unit costs by about $£ 0.40 \mathrm{~m}^{-3}$ to $£ 0.50 \mathrm{~m}^{-3}$ depending on whether the reservoir is natural (clay) or plastic lined, but does provide increased security of supply. An alternative is to abstract from the public (domestic) mains supply which typically costs about $£ 0.90 \mathrm{~m}^{-3}$ to $£ 1.00 \mathrm{~m}^{-3}$. Whilst direct abstraction is currently the most common source of irrigation, insecurity of access to summer water and reduced reliability of flows, coupled with 
possible restrictions on hitherto unlicensed abstractions for drip (trickle) irrigation, and the increasing cost of public mains water are likely to stimulate further investment in winter abstraction and storage (Weatherhead et al., 2014). As a result, the share of irrigation in the total costs of strawberry and other soft fruit production is likely to increase. Furthermore, as irrigation becomes more expensive it is also likely to become more essential for yield and quality assurance. The growers involved in this study confirmed that they could not satisfy premium market quality requirements without irrigation. Failure to achieve Class 1 quality standard would means selling into the processing market, probably with $50 \%$ to $75 \%$ discounts on fresh prices. The imposition of abstraction restrictions during dry years would therefore have severe financial impacts on strawberry growers and consequent impacts on the wider industry.

The water regulation reforms being proposed by the UK government (Defra, 2014a) would create further challenges for the strawberry sector through planned changes in water allocation and the introduction of time-limited licences for irrigation. Many strawberry growers have been exempt from the abstraction licensing regime because drip irrigation, the main system used for strawberry production, has hitherto been unlicensed and unregulated. However, the proposed changes will require all growers to apply for an abstraction licence, including justification that their irrigation demands are 'reasonable'. It is proposed that following successful application, actual annual volumes abstracted will be reviewed after six years and before license renewal to determine whether irrigation has been justified, 'efficient' and constitutes a sustainable use of water. Evidence to support the value of water abstracted will thus be important in justifying future allocations.

The findings reported here also have important implications for informing policy choice. With respect to the planned changes in water regulation, three main options have been proposed: (i) to continue as before, but with limited support for water trading recognising the prospects for more frequent abstraction restrictions; (ii) to establish a system of 'water shares' whereby the burden of restrictions are spread more equitably across sectors rather than for absolute allocations, coupled with enabling or facilitating short-term water trading; and (iii), hybrid approach with elements of (i) and (ii) especially targeted in vulnerable or over-abstracted catchments. The fundamental point is that it is critical to understand the 'value added' by water in high value niche sub-sectors such as strawberry production. It is important, therefore, to recognise irrigation water value (or the potential financial losses from abstraction restrictions) when developing catchment water resource management strategies, including the scope for water trading and potential coping strategies, especially where high value fruit production is concentrated in water deficit catchments. It is also essential in the context of developing collaborative multi-sector or partnership approaches to regional water resource management, which is now being considered in Eastern England to reconcile predicted water supply-demand imbalances due to population growth, socio-economic development and climate change. Finally, there is the drought management perspective. In recent years, the water regulatory agency in England and Wales has developed a positive and proactive approach to communicating with farmers during periods of drought, through meetings, providing information on changing river and aquifer levels, and on future irrigation prospects (Rey et al., 2017). Collectively, these actions have allowed farmers, including those engaged in strawberry production, to respond and adapt their management strategies to changing resource conditions with much greater confidence and to help minimise drought impacts on their businesses.

\subsection{Added value of water}


The average added value of irrigation water for strawberries, at between $£ 4.9 \mathrm{~m}^{-3}$ and $£ 6.6 \mathrm{~m}^{-3}$ depending on variety is relatively high. Equivalent values for supplementary irrigation on potatoes, the biggest irrigated crop by area in the UK, range between about $£ 0.70 \mathrm{~m}^{-3}$ and $£ 1.60 \mathrm{~m}^{-3}$, highest for fresh produce (Morris et al., 2014; Knox et al., 2013). Judged against the counterfactual of rainfed winter wheat, the value of strawberry irrigation water reduces only by about $10 \%$ from the above estimates, suggesting relatively robust demand for irrigation water amongst strawberry growers who might otherwise switch to rainfed arable cropping if water becomes more expensive. Generally, however, the value of water in strawberry production is highly sensitive to the overall profitability of strawberry production; irrigation water values are mainly determined by factors other than irrigation costs, as previously explained. There are also differences amongst strawberry varieties. Irrigation water use efficiency, gross output and gross margins per unit of water appear lower for everbearer crops compared with other strawberry types. It may be economically and environmentally more sustainable to produce 60-day and main-season crops in situations where fresh water availability is particularly limited.

\subsection{Methodological issues}

There is some justification to attribute all of the additional net benefits (revenues less costs) of irrigated strawberry production to water, rather than to other inputs, given the essential, nonsubstitutable value of water in protected cropping systems. Nevertheless, average values could over-estimate the value of water at the margin of use when there is relatively plentiful supply, where water is not considered a constraint, and where it is relatively inexpensive to access and apply. However, as noted by our growers, water supplies are subject to increasing regulations and restrictions, and the cost of securing reliable access whether by means of winter storage or public supply is increasing in real terms.

The enquiry confirmed the difficulties of obtaining sufficiently complete and reliable data on strawberry irrigation practices and costs, mainly because of inherent variability in the context, age, design and operation of irrigation systems, as well as variability in strawberry production systems themselves. For example, irrigation water supply may involve direct abstraction from rivers or groundwater, winter storage reservoirs, or public water supply, or from a mix of sources. Furthermore, growers may simultaneously operate outdoor and 'protected' systems, in soils or artificial growing media, with varying degrees of precision in application of irrigation water, applied to different strawberry varieties and production and marketing cycles. Additionally, soft fruit production and marketing are much more subject to private trading agreements and commercial confidentiality than bulk farm produce: there is sometimes an understandable reluctance to share information even where it is available. For these reasons, generalised estimates of irrigation benefits and costs for strawberry are difficult to make and must be interpreted with caution given the known variation in circumstances and practices.

Our enquiry also confirmed the challenges of obtaining survey-based estimates of the marginal value of water. It requires assessing the impact on profits of increasing or decreasing available water and calculating 'change in profit/change in water use' assuming everything else remains unchanged. Obtaining such information on benefit response to water at the margin is extremely difficult, requiring, for example, experimentation, modelling and/or analysis of data from a large sample of growers using different amounts of water under similar conditions. Furthermore, water resource regulators are particularly interested in 'within season' typically monthly water values to help guide the management of essential supplies during in periods of water deficit (Knox et al., 1999).

Alternatively, the marginal value can be based, not on benefits, but on the cost of substitution, recognising that, even though water is essential, there is usually some scope 'at the margin' 
for water 'saving'. For example, water can be saved by implementing improved irrigation technology, irrigation scheduling and application practices (Daccache et al., 2014; Hess and Knox, 2013). This requires an assessment of the relative cost effectiveness of alternative water saving technologies, where the purpose is to minimise $£$ cost $\mathrm{m}^{-3}$ saved. For technologies to be viable, of course, the marginal cost incurred $\left(£ \operatorname{cost} \mathrm{m}^{-3}\right)$ must be less than the potential loss in marginal revenue $\left(£\right.$ benefit $\mathrm{m}^{-3}$ ) associated with reduced water application. That is, growers must be better off with the technology than without it. The relatively high values (albeit average values) of water use in strawberries derived here indicate there is considerable scope for implementation of water saving technologies.

A further, somewhat theoretical point is worthy of note. The overall profitability of a production system is maximised if returns (that is, value added) are maximised per unit of the most limiting resource. In most farming systems, land has been traditionally regarded as the main constraint with overall profits maximised by selecting land use options with the highest gross margins $\left(£ \mathrm{ha}^{-1}\right)$. In some situations water, labour or investment capital may be the major constraint, and economic efficiency would suggest maximising returns to the factor that is most limiting. In soft fruit production in general, labour has probably been the greatest constraint in recent years, with investments in new systems designed to maximise the size and reliability of returns to labour, essentially through labour saving technologies. Water has not been the most limiting factor. It has probably neither made commercial or economic sense to maximise returns to water per se, beyond of course avoiding unnecessary waste and expense. There are signs, however, particularly in the context of a changing climate and pressure on water resources, that water may become more limiting and expensive (Weatherhead and Knox, 2015).

This in turn will provide incentives for increased water use efficiency and increase the added value from water in the soft fruit sector. The extent to which water is a constraint on soft fruit production will be largely determined by external pressures on water resources, including the need to retain water in the natural environment. Understanding the extent and implications of variations in irrigation practice and performance, and how these affect the efficiency and value of water in use, become all the more important aspects of overall water resource management. With available data, a similar approach could be applied to other crops and agroclimatic conditions to highlight the added value of water for irrigation, and the importance of recognising high-value niche crop sectors when planning to implement changes in regional water resources management or policy.

\section{Conclusions}

There is limited information in the scientific literature and public domain regarding the financial and economic aspects of strawberry (and other soft fruit) production and within this the role of irrigation. Our survey of growers showed considerable variation in irrigation systems and management practices, evident in the wide range of values derived for key physical and financial performance indicators. There are however clear indicators of best practice, usually associated with improved irrigation scheduling and applications, to maximise water use efficiency.

UK strawberry growers increasingly regard irrigation as an essential requirement to assure yield and quality. The average value added by irrigation water in strawberry production is about $£ 6.00 \mathrm{~m}^{-3}$, but there is considerable variation between varieties, growers and production years. In spite of relatively high returns, to date there has been limited attempt by growers to assess irrigation benefits and costs, and hence the value of water. This is mainly because, given the UK's temperate climate, water has until now been readily accessible and irrigation has accounted for a relatively small proportion of total production costs. It is clear, however, 
that a changing climate with greater uncertainty and growing pressures on water resources are forcing a greater interest in irrigation economics in the soft fruit sector, especially in the face of growing restrictions on summer abstraction and rising charges for using public water.

There is also increased importance of knowing the value of water in use, particularly in niche or high added value sectors, in order to support water resource management and policy choice. These in turn are likely to encourage greater adoption of measures such as winter storage to secure access to summer water, alongside those to improve efficiency in use such as better scheduling and precision application. In this context understanding the value of irrigation water is central to supporting decisions by growers and those charged with managing water resources.

\section{Acknowledgments}

The authors acknowledge Defra WU0122 for data acquisition. The assistance of the farmers involved is acknowledged but purposely not attributed. The technical expertise of Richard Harnden (Berry Gardens Growers Ltd), Andrew Hubble (New Leaf Irrigation), John Pelham (Andersons Midlands) and Julian Gruzelier (Netafim UK Ltd formerly Eden Irrigation Consultancy Ltd) are also gratefully acknowledged.

\section{References}

ABC, 2012. Agricultural Budgeting and Costing Book. $77^{\text {th }}$ Edition. Agro Business Consultants Ltd., Melton Mowbray. 473 pp. ISSN: 0952-7605.

ADAS, 2003. Irrigation Best Practice, Water management of soil and substrate-grown crops: A guide for top and soft fruit growers. Grower Guides for Defra. 19 pp. ADAS Consulting Ltd, Stoneleigh.

Daccache, A., Knox, J.W., Weatherhead, E.K., Daneshkhah, A., Hess, T.M., 2014.

Implementing precision irrigation in a humid climate: recent experiences and on-going challenges Agric. Water Manage. 147, 135-143.

Defra, 2010. Report of the fruit and vegetables task force. Department for Environment, Food \& Rural Affairs, London [Online: UK] retrieved 18 Feb 2014 https://www.gov.uk/

Defra, 2013. Basic horticultural statistics 2013. Department for Environment, Food \& Rural Affairs (Defra), London [Online: UK] retrieved 18 February 2014: https://www.gov.uk/

Defra, 2014a.The impact of water abstraction reform. Final Report WT0964/WT0995. Department for Environment, Food \& Rural Affairs, London.

Defra, 2014b. Basic horticultural statistics 2014. Department for Environment, Food \& Rural Affairs, London [Online: UK] retrieved April 2016: https://www.gov.uk/

Defra, 2015. Basic horticultural statistics 2015. Department for Environment, Food \& Rural Affair, London [Online: UK] retrieved April 2016: https://www.gov.uk/

EFFP, 2010. Driving change in the fresh produce sector - Final Report. 27pp. English Food and Farming Partnerships (EFFP), London.

El Chami, D., Knox, J.W., Daccache, A., Weatherhead, E.K., 2015. The economics of irrigating wheat in a humid climate - A study in the East of England. Agr Syst. 133, 97-108.

Else, M., 2012,. Benchmarking in the strawberry sector. Technical Report, EMR, East Malling, Kent.

Else, M., Atkinson, C., 2010. Climate change impacts on UK top and soft fruit production. Outlook Agric. 39(4), 257-262. 
FAO,2014. The agricultural trade indices. FAOSTAT, Food and Agricultural Organization of the United Nations (FAO), Rome. [Online: UK] retrieved 18 February 2014:

http://faostat.fao.org/

Hess, T.M., Knox, J.W., Kay, M.G., Weatherhead, E.K., 2010. Managing the Water Footprint of Irrigated Food Production in England and Wales. In Hester, R.E. and Harrison, R.M. (Eds) Issues in Environmental Science and Technology 31: Sustainable Water. pp.185. ISBN: 9781849730198.

Hess, T.M., Knox, J.W., 2013. Water savings in irrigated agriculture - a framework for assessing technology and management options to reduce water losses. Outlook Agric. 42(2), $1-8$.

Knox, J.W., Morris, J., Weatherhead, E.K., Turner, A.P., 1999. Mapping the financial benefits of spray irrigation and potential financial impact of restrictions on abstraction: a case study in Anglian Region. J Environ. Manage. 58, 45-59.

Knox J.W., Daccache, A., Hess, T.M., Else M., Kay, M., Burton, M., Thelwall, D., Malano, H., 2013. Benchmarking agricultural water use and productivity in key commodity crops. WU0122 - Final Report for Defra. 66 p. Cranfield University, Bedford.

Knox, J.W., Hess, T., 2014. A water strategy for UK horticulture. Technical Report. Cranfield University. [Online: UK] retrieved 3 April 2016 from:

http://horticulture.ahdb.org.uk/sites/default/files/research_papers/Cranfield\%20HDC\%20Wat er\%20Strategy_Final_13May2014.pdf

Knox, J.W., Weatherhead, E. K., Rodriguez-Diaz, J., Kay, M., 2009. Developing a strategy to improve irrigation efficiency in a temperate climate: A case study in England. Outlook Agric. 38(4), 303-309.

Knox, J.W., Kay, M.G., Weatherhead, E.K.,2012. Water regulation, crop production and agricultural water management - Understanding farmer perspectives on irrigation efficiency. Agric Water Manage 108: 3-8.

Morris, J., Ahodo, K., Weatherhead, E.K., Daccache, A., Pater, A., Knox, J.W., 2014. Economics of rainfed and irrigated potato production in a humid environment. In: Bournaris T, Berbel J, Manos B, Viaggi D (eds). Economics of Water Management in Agriculture. CRC Press: 71-97.

NHF,2011. Research into Use: The Strawberry and Brassica crops. National Horticultural Forum, Stoneleigh. April 2011.

Nix, J., 2011. Farm Management Pocketbook. 42 ${ }^{\text {nd }}$ Edition (2012). 284 pp. 8-4. Agro Business Consultants Ltd., Melton Mowbray. ISBN: 978-0-9514588.

Nour, V., Trandafir I., Ionica, M.E., 2011. Ascorbic acid, anthocyanins, organic acids and mineral content of some black and red currant cultivars. Fruits (66): 353-362.

ONS, 2017. GDP Deflators at market prices. Office of National Statistics, London.

Rey, D., Holman, I.P., Daccache, A., Morris, J, Weatherhead, E.K., Knox, J.W., 2016. Modelling and mapping the economic value of supplemental irrigation in a humid climate. Agric. Water Manage. 173, 13-22.

Rey, D., Holman, I.P., Knox, J.W., 2017. Developing drought resilience in irrigated agriculture in the face of increasing water scarcity. Reg Environ Chang doi 10.1007/s10113017-1116-6. 
Weatherhead, E.K., Knox, J.W, Daccache, A., Morris, J., Groves, S., Hulin, A., Kay, M.G, 2014.Water for Agriculture: Collaborative Approaches and On-Farm Storage. FFG1112 Final Report, Cranfield University, Bedford.

Weatherhead, E. K., Knox, J. W, Hess, T. M., Daccache, A., 2015. Exploring irrigation futures - developments in demand forecasting. Outlook Agric 44(2): 119-126 
Figure 1: Cropped area (ha) and production ('000 tonnes) of strawberries in the UK between 1985 and 2014 (Source: Defra, 2015).

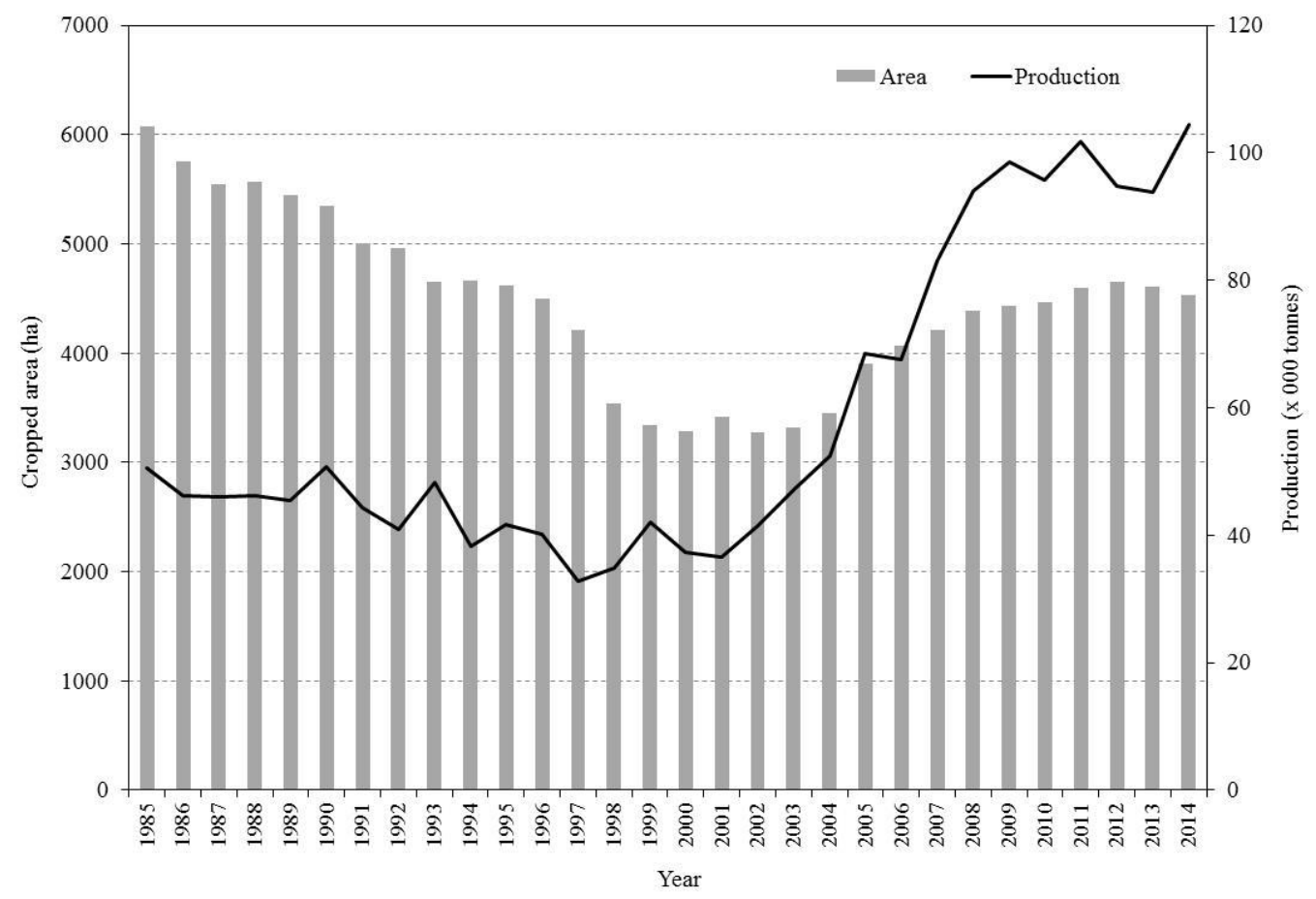

Figure 2: Spatial distribution of irrigation water demand $\left(\mathrm{m}^{3} / \mathrm{km}^{2}\right)$ for strawberries in England and Wales.

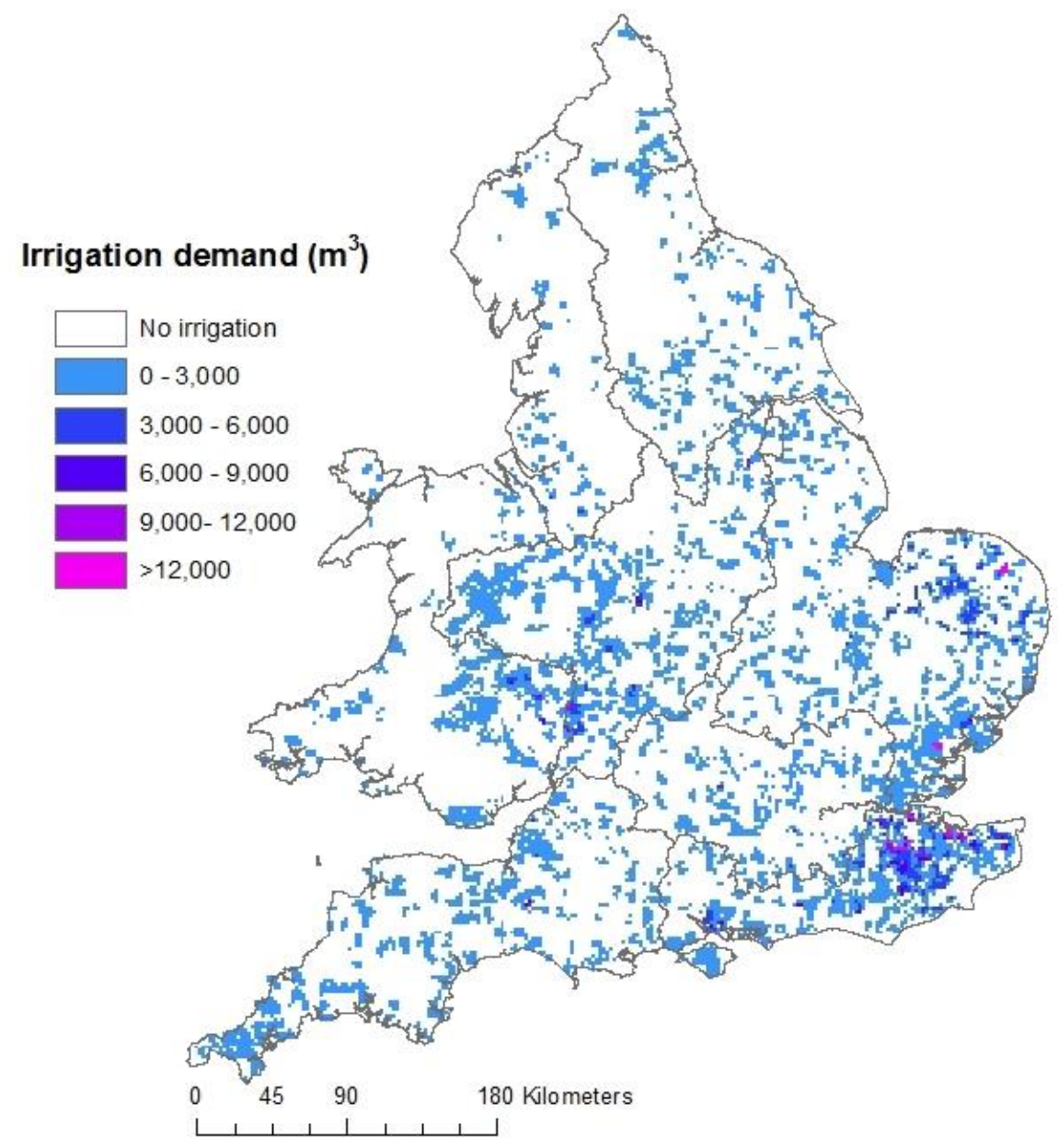


Figure 3: Irrigation volumes, yields and water use efficiency by growers of 60 day, mainseason and everbearer crops in 2011. The first, second and third quartiles (solid lines) and mean value (dashed line) are shown.

(a) Irrigation water volume applied
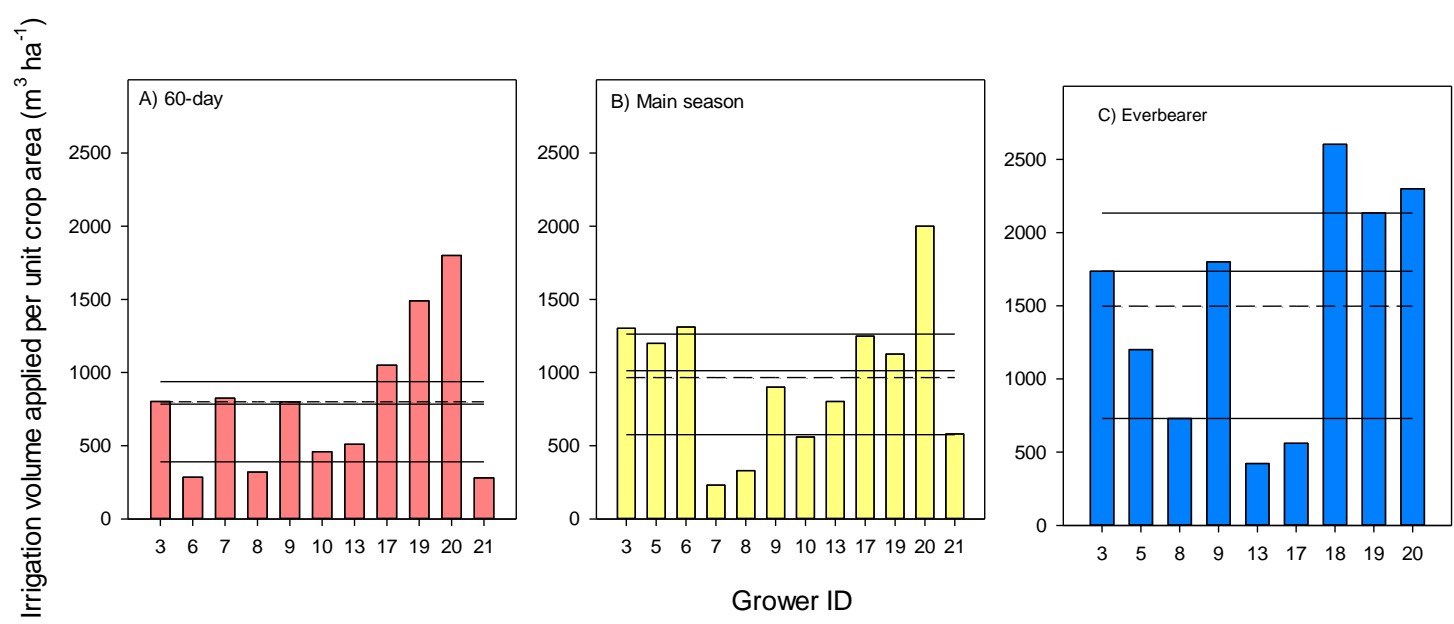

(b) Strawberry yield
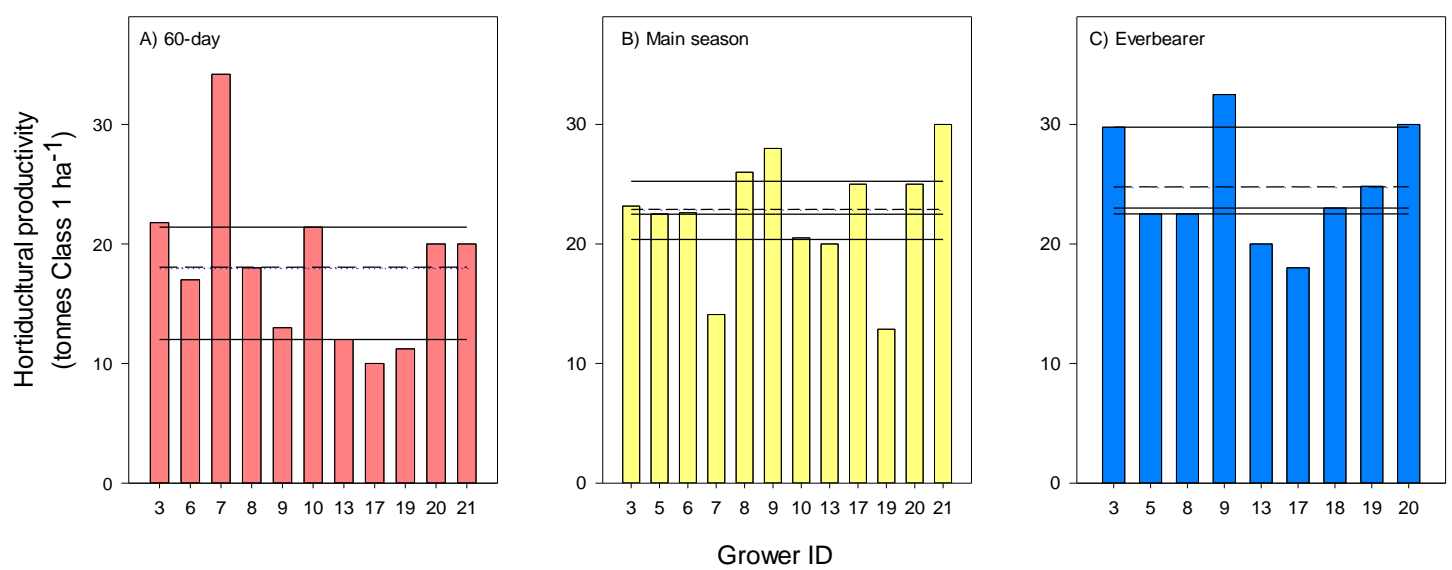

(c) Irrigation water use efficiency
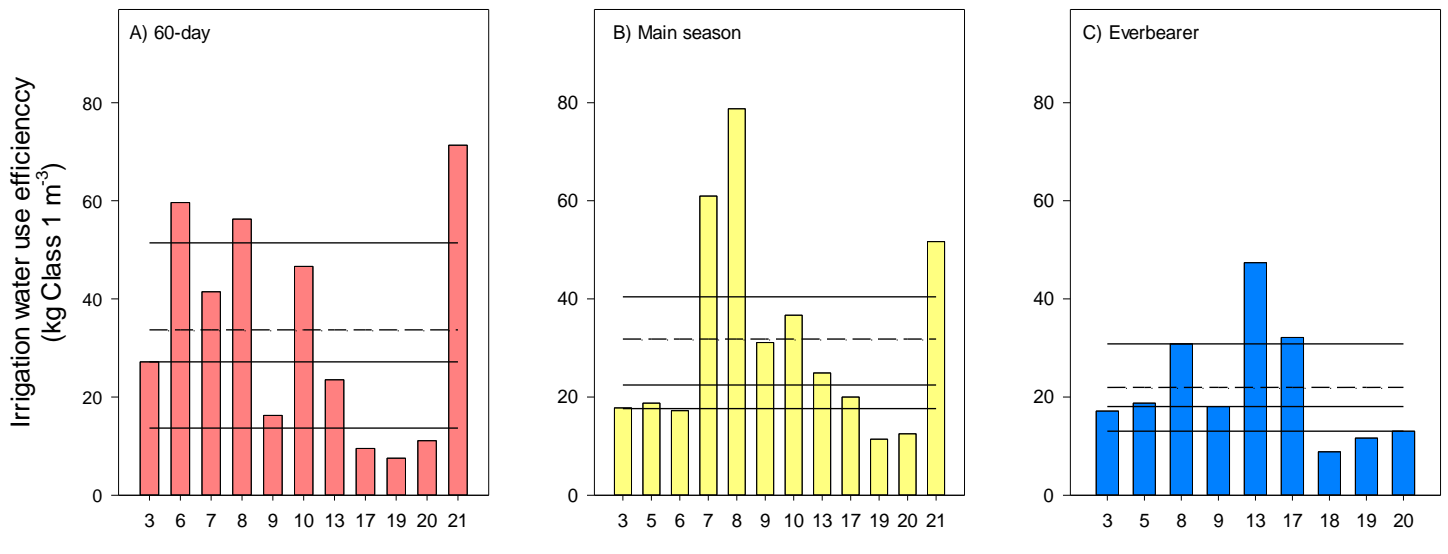

Grower ID 
Figure 4: Irrigated strawberry product value, yields and output per ha and output per unit of water by growers of 60 day, main-season and everbearer crops in 2011. The first, second and third quartiles (solid lines) and mean value (dashed line) are shown.

(a) Product value
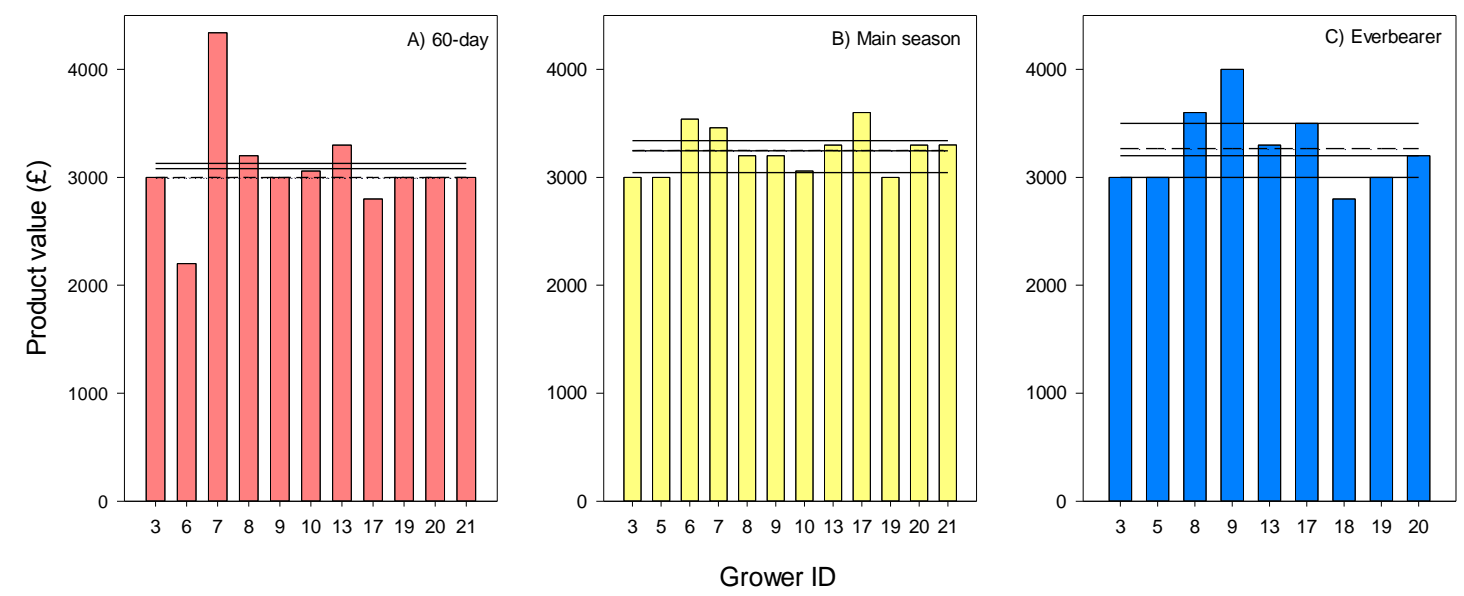

(b) Output per irrigated ha
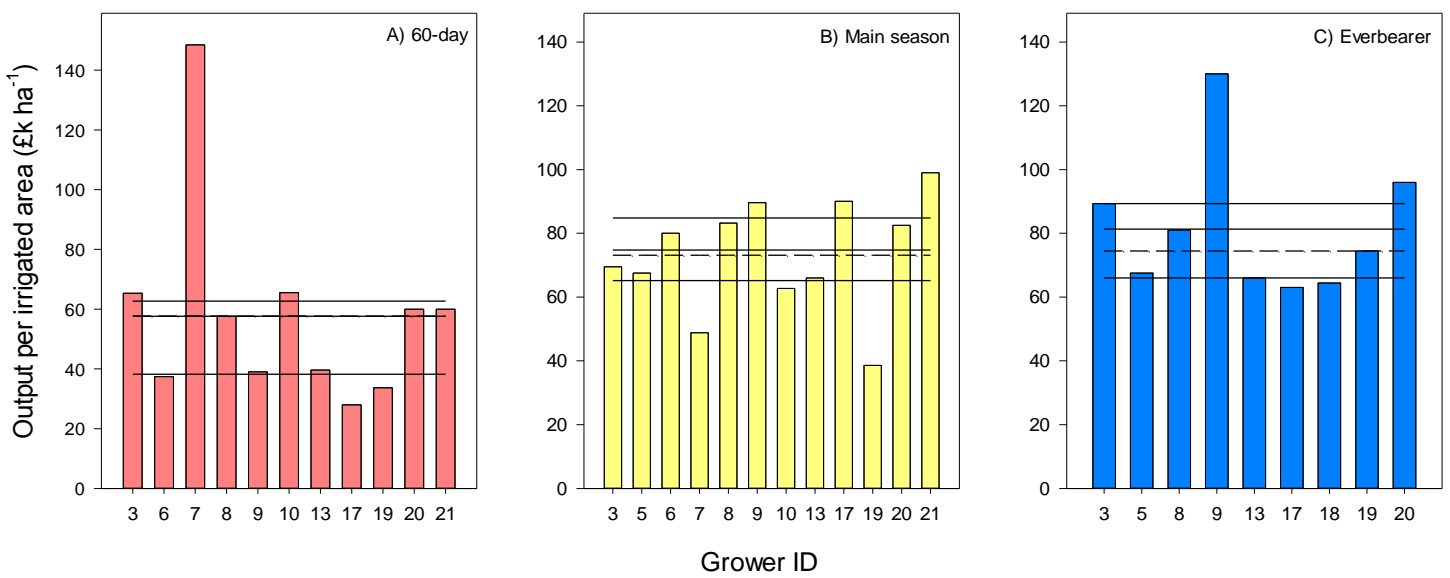

(c) Output per unit of irrigation water
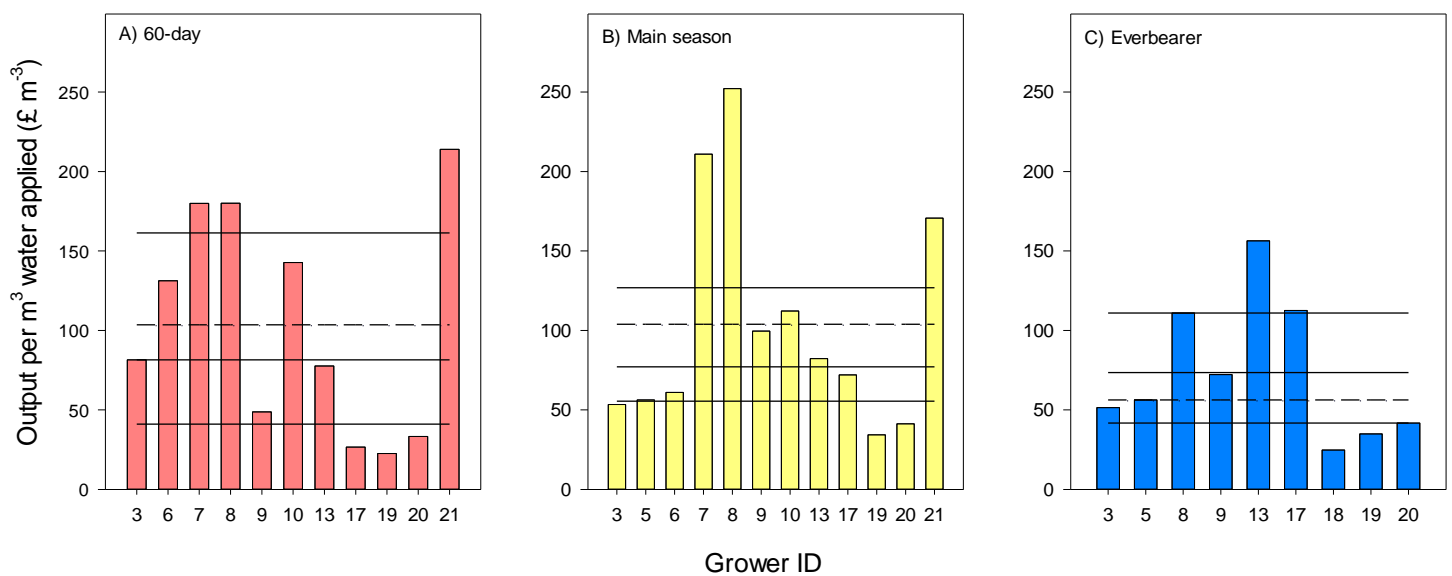
Table 1 Estimated costs of irrigation for three selected strawberry grower cases.

\begin{tabular}{|c|c|c|c|}
\hline Case study & Case A & Case B & Case $\mathrm{C}$ \\
\hline $\begin{array}{l}\text { Strawberry } \\
\text { production } \\
\text { types }\end{array}$ & $\begin{array}{l}130 \text { ha irrigation: } 100 \text { ha } \\
\text { strawberries: } 20 \text { ha } 60 \\
\text { day, } 30 \text { ha main-season, } \\
50 \text { ha everbearer, plus } 30 \\
\text { ha irrigated raspberries }\end{array}$ & $\begin{array}{l}45 \text { ha irrigation: } 32 \text { ha } \\
\text { strawberries; } 19 \text { ha main- } \\
\text { season and } 13 \text { ha } \\
\text { everbearer, plus } 13 \text { ha of } \\
\text { raspberries. }\end{array}$ & $\begin{array}{l}\text { New } 8 \text { ha installation } \\
\text { everbearer strawberries } \\
\text { using raised tables and coir } \\
\text { substrate for production }\end{array}$ \\
\hline $\begin{array}{l}\text { Typical } \\
\text { annual } \\
\text { irrigation } \\
\text { volume }\end{array}$ & $\begin{array}{l}1,800-2,200 \mathrm{~m}^{3} / \mathrm{ha} \\
\text { according to variety }\end{array}$ & $\begin{array}{l}1,250-1,500 \mathrm{~m}^{3} / \mathrm{ha} \\
\text { according to variety }\end{array}$ & $1,500 \mathrm{~m}^{3} / \mathrm{ha}$ \\
\hline $\begin{array}{l}\text { Water use } \\
\text { and sources }\end{array}$ & $\begin{array}{l}200,000 \mathrm{~m}^{3} \text { total }: 50 \% \\
\text { public water, } 50 \% \text { by } \\
\text { gravity from streams/field } \\
\text { drains to lined reservoirs }\end{array}$ & $\begin{array}{l}60,000 \mathrm{~m}^{3} \text { direct } \\
\text { abstraction from borehole, } \\
\text { plus about } 10,000 \mathrm{~m}^{3} \\
\text { public water }\end{array}$ & $\begin{array}{l}12,000 \mathrm{~m}^{3} \text { abstraction to } \\
\text { existing un- lined reservoirs }\end{array}$ \\
\hline \multirow{8}{*}{$\begin{array}{l}\text { Estimated } \\
\text { irrigation } \\
\text { costs and } \\
\text { structure of } \\
\text { costs }\end{array}$} & Capital and fixed costs ${ }^{a}$ & Capital and fixed costs ${ }^{a}$ & Capital and fixed costs ${ }^{a}$ \\
\hline & $\begin{array}{l}\text { Reservoirs ( } 3 \text { lined) total } \\
70,000 \mathrm{~m}^{3} \text { at } £ 5 / \mathrm{m}^{3} \text { in } \\
2012 \text { prices, equivalent to } \\
\mathbf{£ 0 . 4 5} / \mathbf{m}^{\mathbf{3}} \text { storage fixed } \\
\text { costs }\end{array}$ & \multirow[t]{2}{*}{ 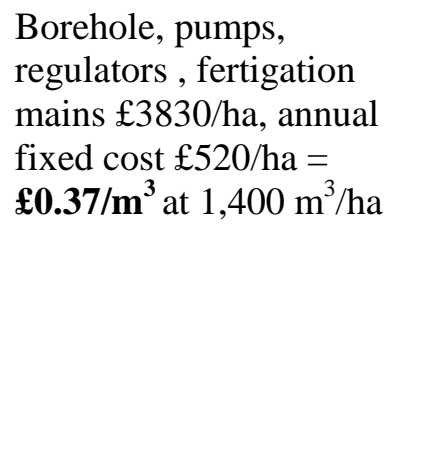 } & $\begin{array}{l}\text { Reservoir (unlined) at } £ 3 / \\
\mathrm{m}^{3}=£ 0.40 / \mathrm{m}^{3} \text { storage } \\
\text { fixed costs } \\
\text { Pumps, generator and } \\
\text { mains } £ 6,750\end{array}$ \\
\hline & $\begin{array}{l}\text { Pumps and mains pipes at } \\
£ 7,400 / \mathrm{ha} \text {, annual fixed } \\
\text { cost } £ 644 / \mathrm{ha} / \text { year }= \\
\mathfrak{£ 0 . 3 2} / \mathbf{~ m}^{\mathbf{3}} \text { at } 2,000 \mathrm{~m}^{3} / \mathrm{ha} \\
\text { applied }\end{array}$ & & $\begin{array}{l}\text { Valves lateral and drippers } \\
£ 10.250 / \mathrm{ha} \text {, total } \\
£ 17,000 / \mathrm{ha} \text {, fixed cost } \\
£ 2,300 / \mathrm{ha} / \text { year }=£ 1.53 / \mathbf{m}^{3} \\
\text { at } 1,500 \mathrm{~m}^{3} / \mathrm{ha}\end{array}$ \\
\hline & Annual operating costs & Annual operating costs & Annual operating costs \\
\hline & $\begin{array}{l}\text { Tapes } £ 976 / \text { ha, energy } \\
£ 108 / \text { ha, labour (and } \\
\text { services) } £ 770 / \text { ha, water } \\
£ 750 / \text { ha }(97 \% \text { of which } \\
\text { public water), total } \\
£ 2,604 / \mathrm{ha},=£ 1.30 / \mathbf{m}^{3} \text { at } \\
2000 \mathrm{~m}^{3} / \mathrm{ha}\end{array}$ & $\begin{array}{l}\text { Tapes and drippers } \\
£ 504 / \mathrm{ha} \text {, energy } £ 145 / \mathrm{ha} \text {, } \\
\text { labour } £ 445 / \mathrm{ha} \text {, other } \\
\text { (transport, repairs and } \\
\text { services) } £ 244 / \mathrm{ha} \text { and } \\
\text { mains water } £ 222 / \mathrm{ha}(97 \% \\
\text { public water), total } \\
£ 1,560 / \mathrm{ha}=£ 1.11 / \mathrm{m}^{3} \text { at } \\
1,400 \mathrm{~m}^{3} / \mathrm{ha}\end{array}$ & $\begin{array}{l}\text { Dripper system repairs and } \\
\text { servicing, } £ 175 / \mathrm{ha} \text {, labour } \\
£ 395 / \mathrm{ha} \text {, energy } £ 105 / \mathrm{ha} \text {, } \\
\text { water } £ 25 / \mathrm{ha} \text {, total } £ 700 / \mathrm{ha} \\
=£ 0.47 / \mathbf{~ m}^{\mathbf{3}} \text { at } 1,500 \mathrm{~m}^{3} / \mathrm{ha}\end{array}$ \\
\hline & $\begin{array}{l}\text { Total average costs = } \\
£ 1.85 / \mathbf{m}^{3} \text { at } 2000 \mathrm{~m}^{3} / \mathrm{ha} \\
\text { applied assuming } \\
\text { reservoir costs apply to }\end{array}$ & $\begin{array}{l}\text { Total average costs }= \\
£ 1.48 / \mathbf{m}^{3} \text { at } 1,400 \mathrm{~m}^{3} / \text { ha } \\
\text { applied }\end{array}$ & 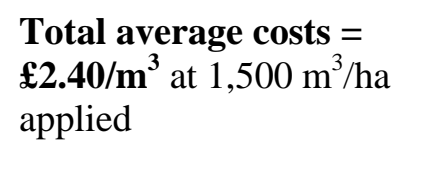 \\
\hline & $\begin{array}{l}50 \% \text { of total water (i.e. } \\
\left.£ 0.23 / \mathrm{m}^{3}\left(£ 0.45 / \mathrm{m}^{3} / 2\right)\right)\end{array}$ & \multirow[t]{2}{*}{$\begin{array}{l}\text { Expected range: } £ 1.20 \text { to } \\
£ 1.80 / \mathrm{m}^{3}\end{array}$} & \multirow[t]{2}{*}{$\begin{array}{l}\text { Expected range: } £ 1.90 \text { to } \\
£ 2.90 / \mathrm{m}^{3}\end{array}$} \\
\hline & $\begin{array}{l}\text { Expected range: } £ 1.50 \text { to } \\
£ 2.20 / \mathrm{m}^{3}\end{array}$ & & \\
\hline
\end{tabular}

\footnotetext{
${ }^{a}$ Capital costs amortized at 6\% over 20 years for reservoirs, 10 years for pumps and distribution systems, and 2 years for infield irrigation tapes.
} 
Table 2: Estimated annual gross output, variable costs and gross margins for $60-$ day/mainseason and everbearer strawberry production in England (source: published and survey data from 2011).

\begin{tabular}{|c|c|c|c|c|}
\hline \multirow{2}{*}{$\begin{array}{l}\text { Component } \\
\text { Outputs }\end{array}$} & \multicolumn{2}{|c|}{ 60-day/main-season crop* } & \multicolumn{2}{|c|}{ Everbearer crop } \\
\hline & $\begin{array}{l}\text { Published } \\
\text { estimates }^{\mathrm{a}}\end{array}$ & $\begin{array}{l}\text { Grower } \\
\text { Survey }^{b}\end{array}$ & $\begin{array}{l}\text { Published } \\
\text { estimates }^{\mathrm{a}}\end{array}$ & $\begin{array}{l}\text { Grower } \\
\text { Survey }^{b}\end{array}$ \\
\hline $\begin{array}{l}\text { Yield }\left(\mathrm{t} \mathrm{ha}^{-1}\right) \\
\text { Price }\left(f 10^{3} \mathrm{t}^{-1}\right)\end{array}$ & $\begin{array}{l}18-23 \\
24-32\end{array}$ & $21.1(10-34)$ & $\begin{array}{r}20-30 \\
25-33\end{array}$ & $\begin{array}{l}26.4(18-32) \\
3.3(28-40)\end{array}$ \\
\hline Gross output $\left(£ 10^{3} \mathrm{ha}^{-1}\right)$ & $\begin{array}{c}2.4-3.2 \\
43.2-73.6\end{array}$ & $\begin{array}{l}\text { 63.6(15-99) } \\
\text { 63. }\end{array}$ & $\begin{aligned} 2.5 & -3.5 \\
50.0 & -99.0\end{aligned}$ & $\begin{array}{r}3.3(2.8-4.0) \\
\mathbf{8 5 . 4}(63-130)\end{array}$ \\
\hline \multicolumn{5}{|l|}{ Variable costs $\left(£ 10^{3} \mathrm{ha}^{-1}\right)$} \\
\hline Plants and plantings & $2.9-3.7$ & & $9.0-15.0$ & \\
\hline Structures & $5.0-8.0$ & & $5.0-8.0$ & \\
\hline Fertilisers/sprays/other & $1.0-1.4$ & & $1.0-1.8$ & \\
\hline Fieldwork & $1.5-3.0$ & & $1.8-3.5$ & \\
\hline Harvesting & $13.0-17.0$ & & $11.0-19.5$ & \\
\hline $\begin{array}{l}\text { Grading/packing/transport/ } \\
\text { marketing }\end{array}$ & $17.8-24.3$ & & $19.9-32.0$ & \\
\hline $\begin{array}{l}\text { Total variable costs }\left(£ 10^{3}\right. \\
\left.\text { ha }^{-1}\right)\end{array}$ & $41.1-57.4$ & $\mathbf{5 7 . 6 ^ { \mathrm { C } }}(14-87)$ & $48.2-79.8$ & $\mathbf{7 6 . 7 ^ { \mathrm { c } }}(55-114)$ \\
\hline Gross margin $\left(£ 10^{3} \mathrm{ha}^{-1}\right)$ & $2.1-16.2$ & $\mathbf{6 . 0}^{\mathrm{d}}(1-12)$ & $1.8-19.2$ & $\mathbf{8 . 7 ^ { \mathrm { d } } ( 8 - 1 6 )}$ \\
\hline Irrigation depth $\left(\mathrm{m}^{3} \mathrm{ha}^{-1}\right)$ & 910 & $\begin{array}{c}910^{\mathrm{e}} \\
(280-2,000)\end{array}$ & 1,760 & $\begin{array}{c}1,760^{\mathrm{e}} \\
(420-2,600)\end{array}$ \\
\hline Gross output $\left(£ \mathbf{m}^{-3}\right)$ & $48-81$ & $70^{\mathrm{f}}(18-252)$ & $28-56$ & $\begin{array}{c}48.6^{\mathrm{f}}(25- \\
156)^{\mathrm{d}}\end{array}$ \\
\hline Gross margin $\left(\mathfrak{E} \mathbf{m}^{-3}\right)$ & $2.3-17.8$ & $\mathbf{6 . 6}^{\mathrm{f}}(1.1-13.2)$ & $1.0-10.9$ & $4.9^{\mathrm{f}}(4.5-9.1)$ \\
\hline
\end{tabular}

*Average annual combined results per ha for a 60-day and follow-on main-season crop.

${ }^{a}$ Published farm business management data (Nix, 2011). Gross output and gross margins are annual estimates.

${ }^{\mathrm{b}}$ Data from 13 survey farms, yields weighted by area, prices weighted by output, and total outputs based on yield and price combinations weighted by area, with range shown in parentheses.

${ }^{\mathrm{c}}$ Based on published estimates, assumes variable costs average $88 \%$ of gross output; equivalent to about $£ 2.70$ $\mathrm{kg}^{-1}$ and $£ 2.90 \mathrm{~kg}^{-1}$ costs for 60-day/main-season crop and everbearer varieties respectively, consistent with total average costs of production reported by growers and industry sources. Ranges based on $88 \%$ of ranges of total output estimates.

${ }^{\mathrm{d}}$ Best single estimates from surveyed farms, with ranges shown: consistent with estimates from published sources.

${ }^{\mathrm{e}}$ Mean $\mathrm{m}^{3} \mathrm{ha}^{-1}$ applied by survey farms, weighted by areas. 60-day/main-season crop based on average of area weighted means. Survey estimates assumed to apply to published estimates.

${ }^{\mathrm{f}}$ Best single estimates for survey farms, weighted by water use, with ranges shown. 